\title{
THE TWO WORLDS OF THE RUSSIAN PEASANT AND URBAN FOLK SONG
}

"Russian folk-music" encompasses an immense variety of narrative songs, ritual and lyric songs, dance songs, topical couplets and laments. Together they comprise one of their richest extant repertoires of folk songs (the repertoire of traditional instrumental music that has survived the persecution of the Orthodox Church and the interdictions of the Moscow Tsars is smaller). This repertoire is subdivided into two major classes of folk-music, differing in origins, structure of melodies and texts, patterns of variation, performance modes and contexts. The first of these classes, the peasant song, comprising numerous genres that exhibit great variation in musical forms, is by far the oldest and the largest. The second, the urban song and instrumental music, less varied, dates back no further than the late seventeenth century. (While primarily secular, both peasant and urban folk-music incorporates a number of religious songs as well.)

The peasant song encompasses the genres and song types characteristic of the most developed repertoires of folk-songs, including, for instance, ritual and non-ritual songs performed in connection with a large number of seasonal rites and holidays, with sowing and harvesting of different crops, with customary forms of communal labor, work chants, ritual wedding praise and dance songs, lullabies, laments of several types, story-telling epic songs, historical songs, song-ballads and 
"spiritual verses", the humorous topical couplet (chastúshki, stradán'), and a large and varied category of lyric songs. It does not conclude the true ballad, however, so characteristic of Western European folk-music. On the other hand, the highly melismatic choral lyric song based on the accordal harmonizing of independent voices known as the "drawn-out" or "extended" (protiázhnaia) songs uniquely Russian (although with parallels in other cultures), and is rightly considered by the Russian people to be the highest achievement of their song-art.

With the expedition of the latter type of peasant lyric song, performed by professional folk-choruses in urbanized variants (for instance, with chordal harmonies, accompanied by an orchestra of "folk-instruments"), and perhaps chastúshki, a late peasant genre that incorporated urban influences from the beginning, the "Russian folk-music" familiar to Western (and, indeed, many contemporary urban Russian) audiences is restricted to the second class, urban music, including nearly all the folk songs composed in the Post-Revolutionary era. This class is structured differently from the class of the peasant song. Thus, the single urban genre of lyric songs includes many types not occurring as peasant lyric songs. For instance, it incorporates a broad spectrum of sentimental songs of the kanto, romance and "gypsy" type, song-walzes, table songs, popular songs on patriotic themes, songs of exile and imprisonment, and the marches and hymns connected with the working-class and revolutionary movements of the late nineteenth and early twentieth centuries. After the October Revolution, songs were composed in the countryside that more-or-less adapted peasant types to urban forms. A number of early Soviet popular songs also belong in the traditional lyric song genre with respect to theme and melody structure. Finally, in recent years the true ballad has emerged as a new genre of urban song.

Below are described the characteristic of some genres and types of Russian peasant and urban songs, illustrated by fragmentary examples: a few measures with a short text line.

The defining characteristic of ritual music is its dependence on performance context. The ritual song has a function, and apart from this function it is not sung. A listener acquainted with the rituals can frequently determine to which an unfamiliar song is attached from the tune alone, since the latter is usually constructed according to a pattern. For instance, according to F.A. Rubtsov, "Almost without expedition, the melodies of calendar songs associated with the summer season, i.e., with the summer-time calendar holidays, Troitsa (pentecoste) and Ivan $\mathrm{Ku}$ palo (Mid-Summer's Day), or with field work (haymoving and reaping), 
are based on a tetrachord within the range of a sixth". (1964. Osnovy ladovogo stroeniîa ruskikh narodnyk pesen. Leningrad, "Muzyka": 31). This observation covers ritual songs proper, performed only in connection with a particular ritual act, ceremonial work songs and the ancient summer lyric songs linked to seasonal activities, but not tied to a specific rite or ceremony. However, it should be noted that each of these types of calendar songs has its own unique melodic characteristics. Moreover, this "summer intonation" also occurs in a large number of ritual wedding songs, which are distinguished from seasonal songs by their syncopated rhythms.

Within the broad category of songs performed seasonally ("calendar songs"), those directly tied to a ritual ("ritual calendar songs"), can usually be distinguished by certain characteristic rhythms and note-rows (tune patterns). Several songs pertaining to the same ritual may be sung to the same tune, which is then called a "pattern tune" or "formula tune". This pattern tune was in effect a "musical signiture", marking the songs as elements of a ritual.

Many of these songs are presumed to be very old, going back to a time before the differentiation of the three East Slav peoples, since songs with texts employing the same poetic imagery expressed in identical musical language are found in parts of Russia, the Eastern Ukraine, Galitsia and the Carpathian Ukraine, regions isolated from each other by the Mongol invasions 850 years ago. "There is no reason to doubt", writes Tat'îana Popova, "that on the whole the oldest stratum of songs of the annual agricultural cycle has come down to our day (with exceptions, of course) in melodic forms approximately as they mere in the twelfth and thirteenth centuries, at the time of Kievan Rus'" (Russkoe narodnoe muzykal'noe tvorchestvo. vyp. 1, Gosmuzizdat, 1955: 88). In some cases, the songs must be even older, since equivalent songs have been recorded in Yugoslavia and Bulgaria.

Evidence accumulated in linguistic and folklore studies suggest that at the time these songs originated, the use of pattern tunes to mark rituals probably had a magical function. Singing the text of a spell was considered essential to make it effective. The act of singing was considered "sacred" (sviatoe), in the meaning given to this word by the PreChristian Slavs: it endowed words and acts performed at the same time with the power of the spirits that augmented their effect. This magical interdependence of words, acts and singing probably explains why the poetic language and melodies of certain conjuring songs have persisted 
virtually unchanged for a thousand years.

Below are partial musical transcriptions of two such ancient calendar songs, the first, a spring "call" (zaklíkàn'e vesny), performed in early March by choruses of girls dressed in their finest on a high piece of ground, such as the site of an ancient gorodische outside the village; the second, performed on the Thursday (Sémik) before Pentecoste (Tróitsa), by girls also dressed in holiday costumes as they wind their way in a procession to the young birch tree selected for "zavivánie": to have its top and branch tips bent into rings and tied, forming living wreaths on the tree. (Note that for the rituals to be effective, it was necessary that the girls look their best, since their beauty was in itself "spiritual" powerful magic; naturally, the most beautiful girl headed the procession.)

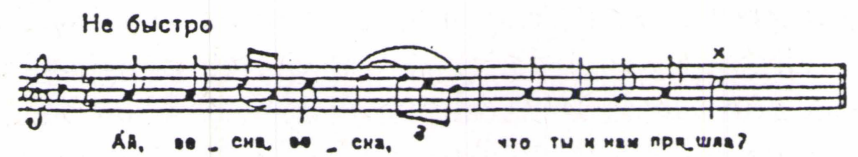

di. 'vesnd, vesni, chto ty is nam prishld?

(oh, Spring, have you come to.us?)

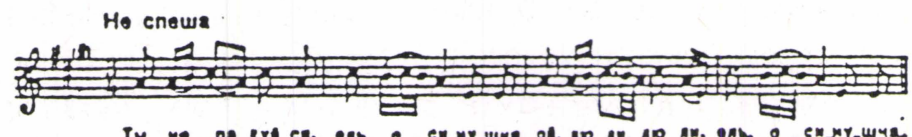

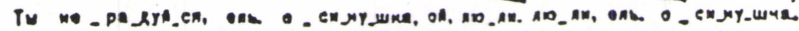

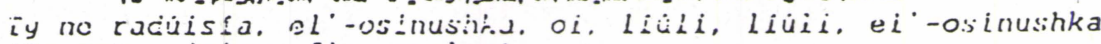
(Do not rejolce, fir, poplar)

Among the most ancient Russian songs are work chants (trudovye pripévki), one of which was made famous by the great Russian singer of the early years of this century, Fëdor Shalapîn: Ei ukhnëm! (Curiously, the words of this chant, razov'ëm my berëzu, razov'ëm my kurdîavu, refer to ritual actions performed by maidens on the last day of the SemikTroitsa ceremonies.) In the nineteenth century, some chants were incorporated into lyric songs about the harsh conditions of labor in Tsarist Russia, becoming refrains that seem to threaten retribution. The lullabies termed báiki, the pribaîútki sung to entertain young children, and many children's game songs comprise another ancient group. In general, Russians grew-up surrounded by singing: as Nikolai Gogol remarked: "The Russian is diapered, married and buried to the singing of peasant women".

At his marriage and burial, the peasant women most likely would have been singing laments (prichéty or prichëty, prichitániîa, voplîa, pláchi), especially if she grew up in North or Central Russia. Lament 
singing occurs among all Slavic peoples, but not all have developed lamenting to the same degree. As Kirill Chistov observes (Prichitanilia y slavianskikh $i$ finno-ugoriskikh nadorov. Obrîad i obrîadovyi fol'klor. "Nauka", Moskva, 1982: 101-114), only a minority have elaborated lamenting as an art-form sufficiently to create the class of weddinglaments. Indeed, among Slavs, wedding laments are almost exclusively a Russian art. And even among Russians, they are not evenly distributed: the most elaborate traditions occur in parts of Central (especially, East Central) and North Russia, where in some districts, all ritual wedding songs, even those in praise of the bride, groom, parents and guests, have been "contaminated" by lament musical motifs, imagery and singing style.

Unfortunately, the distribution of "lament weddings" has not yet been thoroughly mapped. Consequently, I have no way to confirm the impressionistic evidence that in North Russia, they are characteristic of regions either settled from Rostov- Suzdal'îa prior to the fifteenth century, or which had at one time a majority Karelian population. Conversely, in districts of the North settled at an early date from Novgorod-Pskov', wedding laments seem generally to be absent or few, and the melodies of wedding songs appear more often to be based on the intonation of the summer calendar songs (see the remarks of Balashov and Krasovskaîa in the introduction to Svadebnye pesni Terskogo berega Belogo morîa, Leningrad, 1967). In the previously cited paper of Chistov, he notes that Russian wedding lament traditions appear to have been most developed in regions contiguous to, or formerly inhabited by, Fennic peoples, among whom wedding laments also achieved their greatest development. This would apply to Karelians in the Lake Onega region east to the Onega River, and the Mordvin and Komi-Zyrian peoples, especially.

Despite the evident relationship between Russian and Fennic lament traditions, it is important to point out that the laments themselves differ substantially, notably, in the construction of the texts. Musically, on the other hand, similarities sometimes can be detected, for instance, in the Olonets and Onega regions, where lamenting and the chanting of epic poems, stariná (whence comes the Finnish word, "tarina"), are closely linked. Reference is sometimes made, therefore, to a "lyrico-epic lament tradition" in this region. Wedding songs may exhibit a relationship to song-epics, but this occurs also in districts of the North, where lament weddings are not characteristic.

Below is a fragment illustrating one of the salient features of many 
funeral laments: apocope. The musical phrase, based on a descending third or fourth, is generally shorter than the text line, so that the verse ends with the last word having to be partially swallowed, as if by a sob. This is a well thought-out technique for artistically employing the natural sob, the singer being literally forced to gasp out the final syllables, in order to maintain the rhythm, which like the scalar structure is highly stereotyped. The verse lines themselves must be improvised, employing a large stock of set phrases and metaphorical expressions.
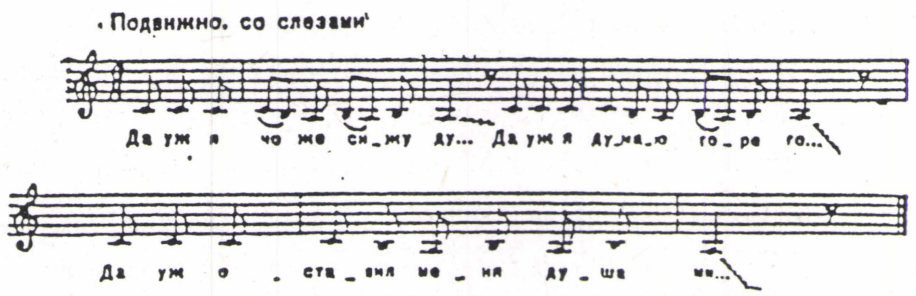

Da uzh $i$ a cho zhe sizhú du... Da uzh [a dúma[u gore go... [revat']

Da uzh ostávil menía dushá mí... l logo!

(I sit all the time and think bitter grief: the soul of my beloved has left me)

Wedding laments vary not only between districts, but even within the same ceremony. In general, the texts are highly metaphorical, while the melodies may converge strongly towards the women's lyrical song. Indeed, lyrical songs occur, both wedding and non-wedding, that exhibit features of the lament, including use of the same metaphors and a dispropotion between melodic and text lines, that allows for the insertion of cries, $o i, a a$,etc., at the end of musical phrases. Another group of lyric songs, derived directly from laments, have melodies based on a descending fourth, but elaborated by the melodic extension of syllabes that creates intersyllabic rhythms.

In its most developed form, the Russian wedding was literally a theatrical production, with a director (called drúzhka), who had also to be able to magically "protect" the bride and groom, and magically assist the success of their union, and "actors" playing assigned parts (some 400 terms have been collected from various populations of the three East Slavic peoples for these rôles). On average, the principal rituals, twenty or more, took a week to perform.

Singing was so much a part of the Russian wedding that it could not be performed without the necessary songs. Every stage in the ceremony (every one of its numerous "scenes") had its songs. A constant feature was the chorus of women, who performed the ritually required songs at the appropriate times and places. Especially in the North, functionally 
similar songs were performed to a pattern-tune, which undoubtedly had the same magical purpose as the use of pattern-tunes for calendar songs. In those districts of North and North Central Russia, where group wedding laments were developed (e.g., in Iaroslavl', Kostroma and eastern Vologda regions), the chorus performed these. In this case, the bride and chorus often lamented antiphonally, to different words and in different rhythms. The use in wedding songs of rhythmically assymmetrical pattern-tunes repeated over and over, plus the constant antiphonal lamenting, created extreme emotional tension in both the principal players and their relatives and friends assigned lesser rôles.

The diacnostic characteristic of Russian wedding songs is not their melodies as such, which converge on laments, ritual calendar and lyric songs, but their rhythms. The most complex rhythms in Russian folkmusic occur in pattern tunes for ritual wedding songs. Metre is irregural, often with rapid alternation between duple and triple units: $(3+3+2) / 8$ $(3+2+2) / 8(3+2+3+3) / 8(2+2) / 8$. The effect is hypnotic (V. Lapin. Napevy svadebnykh pesen Pomorskogo berega Belogo morîa. Fol'klog $i$ etnografiîa: obrïadovy fol'klor. Leningrad 1974). According to Zemtovskii, the most frequent rhythm in quintuple, especially in the combination, $5+3$.

The distinguished feature of Russian figure-dance (khorovódnye) songs is the articulation of independent musical phrases, each of which is repeated, often in the pattern, AABB. Actually, Russian peasants did not "dance" khorovódy, they "conducted" them (vódiat khorovód), in the sense either of conducting a theatrical piece (acting it out), or of conducting a ceremonial procession (hence, also the expression, "to parade in a khovoród" [gulîat' khorovódom]). Many khorovódy undoubtedly had their origin in sympathetic magic, whereby acting out the processes of, for instance, sowing, harvesting, retting and crushing flax, combing and spinning the fibres into thread, and weaving linen cloth, all accompanied by the appropriate lines of text in a song, was supposed to have a positive effect on the actual production of linen. Usually, the work theme was combined with a marriage theme, reflecting the connection between calendrical rituals, whose function was magically to ensure the harvest, and the wedding ceremonial, which seems originally to have fulfilled the magical function of renewing fertility. However, today these actions are performed as a theatrical game-dance (igrísche), although in some regions of South-West Russia, they were still being performed in a ritualistic manner a hundred years ago. Zguta suggests that 
in the Middle Ages, mass theatrical rituals of this sort were conducted by skomorókhi, one or more of whom would imitate the work processes inside the circle formed by the dancers, but that with the suppression of these professional actors after 1648, this type of theater-dance turned into a game (R. Zguta, The Russian Minstrels. Clarendon Press, Oxford, 1978: 108).

Processional khorovódy were performed by maidens in costume as part of spring calendar rituals, at the beginning of field-work and during the Semik-Troitsa cycle, especially. They are mass dances, in which a hundred or more girls might take part. Later, khorovódy began to be performed during Máslenitsa (Shrovetide week) as well. They also form part of the wedding ceremony in most regions, often being danced to short wedding verses (pripevki), especially in the Russian North, where they are termed kruzhki, gorodkí, úlochki, etc.

True to their origin, khorovódy have to be performed in unison. At one time, as the name suggests, they were always performed in a closed circle, a magically impenetrable ring (today, many other configurations are possible). It is still a requirement that when forming a figure, dancers should be in some sort of physical contact, coordinating both steps and body movements. Typically, the khorovód gives the impression of "flowing" or "rippling". In play dances (igrischa), the words of the song are acted out inside the "magic circle".

In contrast to figure-dances, Russian step-dances, plîáski, are performed mainly to songs borrowed from other genres. They are danced by an individual, alone or with a partner: when several individuals or couples dance at the same time, each performs his own steps and patterns (exceptions exist). Since skill is emphasized, steps tend to be difficult and the tempo fast. Unlike khorovódy, characterized by assymmetrical rhythms and unequal metres, plîaski are rhythmically simple, the melody comprising a set of short repeated phrases, often with identical rhythm patterns. Frequently plîaski are danced to the witty, humorous or satirical, couplets called chastúshki, accompanied by an accordion. The words of a classic plîáska song, the kamarínskaîa, containing references to sexual intercourse, have never been published in the Soviet Union, and today, the kamarínskaîa is performed solely as an instrumental piece.

As a rule, most types of Russian peasant songs were meant to be sung "collectively", by two or more singers. This emphasis on group performance is reflected in the structure of the texts and melodies of calendrical and wedding songs, khorovod dance songs and "drawn-out" 
lyric songs. With the exception of individual laments, the only major category of traditional songs that can be said to have been adapted specifically to a solo voice is the Russian epic song as it was performed along part of the White Sea Coast and the Mezen's River. In some other districts of the Russian North, as well as in the Don Cossack country, even byliny epics were sung chorally, which tended to transform them into lyric songs.

Another catecory of Russian peasant narrative "song", the so-called ballads, were in fact more like folk-tales recited in song. They had no melodies of their own, but were set to whatever was available and appropriate to the context in which they were performed. Thus, when sung at a wedding, the story would be set to a wedding tune; in a collective of laborers (artél'), to the tune of a men's (molodétskaîa) lyric song; in a barracs, to that of a soldier's song; etc. There is evidence that a several hundred years back, some of the wonder tales (volshébnye skázki) were also "recited" as songs.

One group of narrative songs has been all but ignored since the Revolution: the so-called "religious verses" (dukhóvnye stikhi). These are an important source for studying the psychology and world-view of Russian peasants, notably, their most articulate representatives in the era prior to the emergence of mass revolutionary movements: the Old Believers (Starovéry, Vanhauskoiset) and secterians (Khristovovery, Khlystsy, Dukhobortsy, Molokany, etc.). Dukhóvnye stikhí are very heterogenous. Generally, though, they can be divided into a stratum of songs much like byliny epics, dating to the earliest days of Christianity in Russia, the oldest of which clearly derive from Pre-Christian sources (e.g., the stikh about George-the-Brave and Elizabeth-the-Beautiful: vid.: V.îa. Propp. Zmeeborstvo Georgî̀a v svete fol'klora. Fol'klor $i$ etnografîa Russkogo Severa. Leningrad 1978: 190-209); and a much later stratum, closer to the lyric song, composed mainly as expressions of religious devotion and suffering by individual members of the Schism (Raskól). Among the latter, stikhi that became part of the song-services of the Molokán sect are especially interesting, since some preserve ancient musical forms.

The lyric song is without doubt the most complex, as well as the largest, genre of extant Russian peasant songs. I have already mentioned several types: lyric calendar songs (the oldest), lyric wedding songs, lyric songs derived from the lament, lyric epic songs, lyric spiritual songs, and the lyric "drawn-out" song, cited at the beginning of this es- 
say as the musically most developed peasant song type. Below is a fragment illustrating the characteristics of "drawn-out" songs: the drawing-out of a single line of text over several measures of the melody, determined by the number of syllables without regard to word stress (raspéty stikh); breaking-off of words (apocope), repeats, interjection of vocables even within words, etc.; free intermingling of voices, all singing versions of one tune, occasionally producing chords, more often moving in parallel or in unison, sometimes crossing; the stressing of the key notes in the raspév, or melodic motif, by the chorus singing in unison; beginning and ending of the song on a single note rather than a chord. A song leader, or zapevála, is characteristic of the most, but not all local traditions. Major differences exist between regions in the way voices are combined during descant singing (called pogdoláshivat', or "to sing in supporting independent voices"), in desired vocal qualities and singing styles: e.g., in the North, the style favored is one in which the lead singer stays close to the chorus; by contrast, in the South the lead singer tends to be more independent; generally, the voice is less tense in the North.
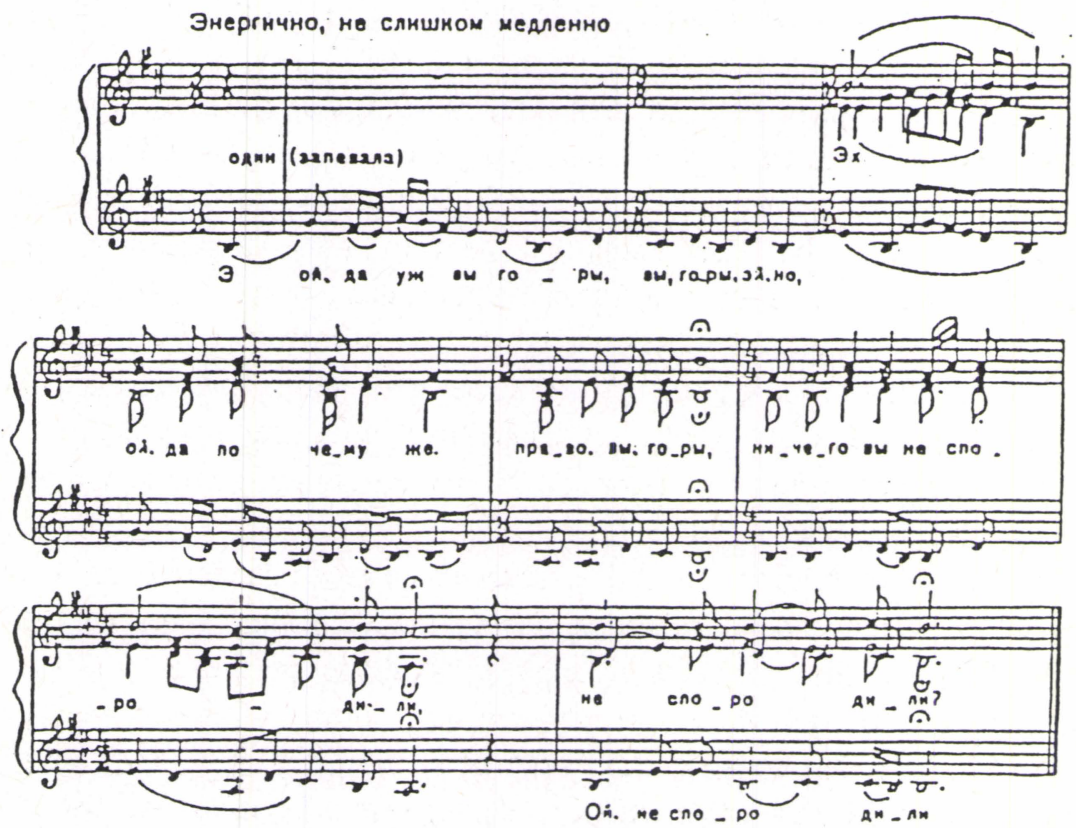

E-ol, da uzh vy gory, vy góry, ei, no, oi, da pochemú zhe, právo, vy góry, nichegd vy ne sporodlli, ne sporodlli?

(Why, oh mountalns, why have you, in truth, begot nothing?) 
The last genre of Russian peasant music about which I'll write a few words is the chastúshka, a rhymed four-line (usually) couplet, originally linked, as noted earlier, to the Russian step-dance (plîáska). Hardly a century old, this is the only extant genre of the Russian peasant song that from the beginning has been accompanied on an instrument. Indeed, it owes its origins in part to the spread of the accordion in the Russian countryside after 1830. Especially after the abolition of serfdom in 1861 , the old spoken verse dance pripevki began to be accompanied on the accordion. This opened-up a whole new range of possibilities for the development of improvised rhymed verses and pliáski steps, which helps to account for the great popularity achieved by the accordion and its cousin, the concertina, in the Russian village at the turn of the century. Once the chastúshki form had become established, they began also to be accompanied on the balalaika, encouraging adoption of the latter in the villages as well.

As an art-form, the chastúshka couplet owes another part of its origins to the farces and episodes from the life of the puppet, Petrúshka, staged by skomorókhi during Shrovetide Week (Maslenitsa) and at fairs (îármaki) held on Alter-Holidays (Prestól'nye Prazdniki), when they would recite satirical verses in call-response fashion. Similar couplets at one time were improvised and recited at weddings as mock praise-refrains by comedians, drázniki, who also may have been skomorókhi.

The chastushki came into their own in response to rapid chance in village life during the latter nineteenth century, when a medium was needed in which to comment on these changes and to express new ideas in a traditional manner. As a result, the themes of chastushki are much more numerous and varied than those of the other genres of the Russian peasant song. Musically, too, chastushki have quite sophisticated, and they are now more often performed by themselves, as topical songs, than to accompany dances.

Just as the origins of the chastushki were connected to the emercenge of new social relations during the declining years of the Tsarist Empire, the "drawn-out" song took shape in the era of the "gathering of Russian lands" around Moscow that culminated in the formation of the Tsarist State. Its status as the uniquely "Russian" song form, not shared by the other East Slavs, suggests it became established at about the same time differentiation of the Russian nationality was completed.

On the other hand, extended singing of lyric songs did not develop 
in those regions of Ancient Rus' that, while historically "Russian" (Veliko-Rus'), were not included in Moscow Russia during the sixteenth century: extreme western, southwestern and northwestern districts of modern-day Smolensk, Brîansk and Pskov regions, and in part, adjacent districts of the Western Ukraine. In the era of the Moscow Tsardom, these districts formed part of Lithuania and Poland. Beginning in the reign of Aleksei Mikalovich, the second Romanov Tsar (1645-1676), the southwestern lands became a major conduit of Western European influences on the culture of Moscowy: from there came the primary stimulus that gave birth to Russian "urban" folk-music in the first decades of the eighteenth century.

The Southwest played a major rôle in the cultural politics of the early Romanov Tsars, because it was only in the regions of Ancient Rus' not under Moscow rule that Orthodox churches remained under the jurisdiction of the Greek Patriarch after the Florentine Uniate and conquest of Constantinopole by the Ottoman Turks in 1453. In this region, Aleksei Mikhailovich sought to find Rus', among whom the traditions of the Imperial Byzantine Church had been preserved. For unlike the Tsars of Moscowy, who had looked askance at this tradition, compromised, in their view, by the uniate with the Catholic Pope, the new Romanov Tsars looked to the cultural models created by Imperial Byzantium for validation of their new status as Emperors of All the Russias. Whereas in Moscowy the Tsar had taken the place of the discredited Byzantine Emperor, and Moscow had become the Third Rome as the last stronghold of Orthodoxy, the Romanov's viewed the Tsar as the new Emperor, and the Third Rome as the heir to the Byzantine Emperor itself. The idea of creating a new universal Orthodox Empire meant abandoning cultural isolation, which the Moscow Tsars had seen as necessary to maintain the purity of the Orthodox faith.

Thus, the Russian "drawn-out" lyric song and "urban" lyric song were shaped by cultural-historical environments that in some respects were diametrically opposed: whereas the former came into existence in an era of self-conscious religious, political and cultural isolation, the latter was created in an era of equally self-conscious borrowing of religious, political and cultural forms, which, if nominally Byzantine (and, therefore, from the supposed parent tradition of the Orthodox Church and Empire), were in fact thoroughly "contaminated" by Western European influences, stemming from centuries of political dependence of the southwestern Russian, Western Ukrainian and Belorussian populations on Catholic Poland. During the reign of Peter the First and his succes- 
sors, of course, this Western European influence became open and direct.

Not surprisingly, considering their source, the earliest urban lyric songs were created on the basis of the new system of harmony workedout for composing church hymns. (Harmonized hymns, by the way, were rejected by the Old Believers, whose religious music can preserve old types.)

The feature that distinguishes the urban lyric song, no matter what its type, is that almost without exception its melody is based on harmonic chords. This feature is so distinctive that one can be positive any Russian song in the chordal-harmonic system is "urbanized", and therefore, not older than the eighteenth century; moreover, if the tune is not in kant form, it most likely was composed not earlier than the nineteenth century.

A second feature of the urban lyric song is so-called tonic syllable versification, that is, verses constructed according to literary norms, sung with the stressed syllables musically accented, i.e., "correctly", in accordance with the canons of Western European music. This is an important distinction on both counts: verse length and stress of peasant songs are typically irregular, while it is common to accent musically syllables other than the tonic ones, a stylistic device widely employed in certain peasant song genres (especially, epic songs, laments, wedding songs and "drawn-out" songs). Tonic syllable versification, however, is not as distinctive, both because some urban lyric songs have verses composed by poets in "peasant" style, and because many nineteenth century lyric songs originating in peasant surroundings (not to mention chastushki!) have symmetrical rhymed verses constructed according to "book rules".

The earliest urban songs are kanty, a song that in its simplest (and initially most widespread) form was constructed of two more-or-less identical musical statements (each often of two phrases, symmetrically "squared"), in three parts: the upper two in parallel thirds matched to a more independent base. The oldest kanty were probably composed about 1670 , as religious hymns. Secular kanty, in anonymously written manuscripts, are common from the first half of the eighteenth century. Many of these, undoubtedly, were improvised by students, soldiers, clerks, etc., and existed in oral transmission before someone decided to put them on paper. Being symmetrical with simple regular rhythms, they were easily learned and memorised. Until about the second decade of the 
eighteenth century, kanty were generally sung unaccompanied, probably because of a lack of harpsichord, etc., rather than for any musical reason - they are "made" to be accompanied on harmonically tuned instruments. In principle, the kanty can be considered the ancestor of all later urban songs, no matter how far they have diverged from this basic pattern. Below is an example of a three-part eighteenth century sailor's kant, illustrating some of the features described:

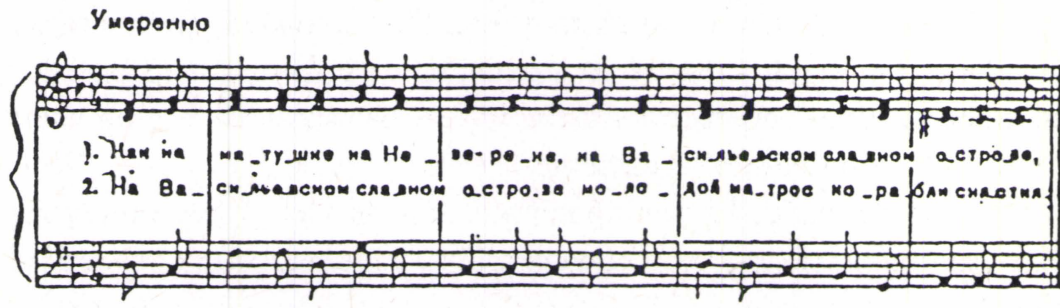

1. Kak na mátushkè na Nevé-reké. na Vasil'evskòm slávnom ostrovè.

2. Na Vasll'evskòm slánnom óstrovè molodói matrós korabll snastll.

(On Mother Neva river, on renowned Vasll'ev Island, a young sallor was equipping ships).

I will close this all-too-brief survey of the Russian folk-song with a few words about its status in the Soviet Union. Firstly, it should be noted that over much of Russia, the ritual calendar and wedding songs, among the most ancient and distinctive peasant genres, were already on their way to extinction before the Revolution. Secondly, the penetration of the urban style of music into the countryside had begun long before, and new synthetic forms, like the chastushki, had existed for decades, alongside numerous peasant lyric songs based on urban models. Even traditional "drawn-out" songs were being reconceived according to the tonic syllable and chordal harmonic systems, the verses reshaped "correctly" and sung in "perfect" harmonies. Thirdly, a large number of purely "urban" songs had been widely adopted by the peasantry, ranging from "gypsy" romances to revolutionary marches. The Revolution intensified these processes: it was not their cause.

On the other hand, collectivization dealt a fatal blow to virtually all aspects of traditional culture, not least the traditional peasant song. The communal and family rituals and relations that had nurtured these songs for centuries were suppressed. The government and Communist Party sometimes put considerable pressure on the peasants to abandon their old songs and adopt new Soviet songs, constructed without exception according to the canons of "correct" composition (oni schitaîutsîa 
gramotnymy). In those years, the official musicological establishment tended to be no less devoted to propagating the "progressive" forms of harmony and versification. This was evident not only in text-books, but in the selection and "arrangement" (in fact, not infrequently, total rephrasing) of songs for the folk-choruses. As the latter became increasingly professionalized, that is, composed of singers trained solely in the Western European system, they ceased even to be able to perform traditional peasant songs, about which they had little knowledge. Naturally, few of these traditional songs were broadcast or performed on stage: for about three decades, no records were issued of peasants singing their songs as they would among themselves.

On the other hand, beginning early in the Soviet years, numerous expeditions were sent out to record peasant songs and other aspects of folklore all over the country. In the 1960s, several large-scale long-term complex expeditions began to record songs and entire rituals in several districts of the Russian North and Siberia that had remained relatively isolated (they were areas with large Old Believer populations before the revolution). Ethnomusicology, as a science distinct from musicology, seems to have reappeared at about the same time. Peasant singers, as opposed to folk choruses, began to be recorded, while students of the new Gnesinykh Pedagogical Institute attached to Moscow Conservatory began to reproduce peasant singing with great fidelity and skill in public performances.

Today there are signs of a healthy revival of interest in the traditional peasant song-art, although still confined within a fairly narrow segment of the Soviet public. Current efforts underway to recover the best aspects of traditional Russian culture deserve to be encouraged. In particular, Russian peasants created superb works of art ranging from the monumental log churches, chapels and dwelling complexes of the North to the striking costumes of peasant women in Tambov, Orël and Vorozneh regions that should be treated as national treasures, contributions of the Russian people to world culture. The art of the Russian peasant song is surely no less of a treasure. 